\title{
Scanning Electron Microscopy of the Surface Epithelium of the Pig Ovary
}

\author{
Hajime Miyamoto, Ryosuke Furubayashi and \\ Takehiko ISHIBASHr \\ Faculty of Agriculture, Kyoto University, \\ Kyoto-shi 606
}

(Received April 10, 1982)

\begin{abstract}
Some structural features of the surface epithelium of the pig ovary were examined by scanning electron microscopy. There were no vesicular follicles visible on the ovarian surface of the infantile pig (13 days of age), and their surface epithelium consisted of polygonal cells that had numerous short microvilli and a few isolated ciliumlike processes. In the prepuberal ( 6 to 7 months of age) or postpuberal pig ovary, the surface epithelium was observed at a low magnification as a continuous cellular layer. In these pigs the surface epithelium over the vesicular follicle generally consisted of polygonal cells covered with numerous microvilli. The presence of a small number of long cilium-like processes among the microvilli was also noted on the epithelial cells covering the follicle. The size of surface epithelial cells over a large follicle appeared to be somewhat larger than that of those over a small or a medium-sized follicle. The surface over the ovulated follicle (corpus luteum) differed in structure from the preovulated follicle. Epithelial cells covering the apical region of the ovulated follicle were scarcely observed at early metestrus, although whenever such existed, the cells possessed fewer microvilli than did the cells over the pre-ovulated follicle. In general, the cell borders at the apical region of the ovulated follicle were indistinguishable at metestrus even if cells were observed, but became distinct during diestrus. However, in other regions, the structure of epithelial cells covering the ovulated follicle appeared to be about the same as that of those covering the pre-ovulated follicle. It appears that the morphological features of the surface epithelium of the pig ovary are similar to those of laboratory animals and primates. Jpn. J. Zootech. Sci., $53(10): 692-698,1982$
\end{abstract}

The surfaces of mammalian ovaries are covered with a surface epithelium. Scanning electron microscopic observations have been made on the surface epithelium covering ovarian follicles of the mouse ${ }^{1-3)}$, rat $^{1,3-5)}$, hamster ${ }^{5,6)}$, guinea pig $^{1)}$, rabbit ${ }^{1,3-5}$, ${ }^{7,8)}$, monkey ${ }^{4}$ and human ${ }^{1,49}$. However, such observations have not been made on farm animals.

The morphological changes in the ovarian surface epithelium that occur during and subsequent to ovulation are probably associated with the progressive degeneration of the cells ${ }^{1,2,8,10}$ ). The surface epithelium may contribute to the production of proteolytic enzymes which help to disintegrate the follicle apex prior to rupture ${ }^{\mathrm{in}}$. In general, the microvilli on the surface epithelium of organs within the body cavity increase the physiologically active surface area of the cell ${ }^{6}$.

The present scanning electron microscopic study was designed to examine the fine structure of the surface epithelium of the pig ovary. 


\section{Materials and Methods}

Ovaries from 2 infantile (13 days of age), 4 prepuberal (6 to 7 months of age) and 10 postpuberal Landrace pigs were obtained at slaughter. The number, size and conditions of vesicular follicles and corpora lutea visible on the ovarian surface were examined to determine the stages of the estrous cycle ${ }^{12-14}$. Ovaries were gently washed in $0.1 \mathrm{M}$ phosphate buffer, pH 7.2. Then 10 to 20 follicles for each of three size classes $(1 \sim 2 \mathrm{~mm}, 3 \sim 5 \mathrm{~mm}$, and $6 \sim 12 \mathrm{~mm})$ and 5 to 10 corpora lutea for each stage of the estrous cycle were dissected from the ovaries. Ovarian surfaces that were not in contact with follicles or corpora lutea were also dissected.

The tissues were fixed for 6 to $8 \mathrm{hr}$ at $4^{\circ} \mathrm{C}$ by immersion in a solution of $2.5 \%$ glutaraldehyde in $0.1 \mathrm{M}$ phosphate buffer and cut into small blocks with a razor blade. After immersion for 12 to $15 \mathrm{hr}$ in the same buffer, the specimens were post-fixed in $1 \%$ osmium tetroxide buffered with $0.1 \mathrm{M}$ phosphate ( $\mathrm{pH} \mathrm{7.2)}$ for $3 \mathrm{hr}$ at $4^{\circ} \mathrm{C}$ and then dehydrated in a graded series of ethanol. From 100\% ethanol the specimens were transferred to iso-amyl acetate. Following serveral changes of iso-amyl acetate they were dried with liquid $\mathrm{CO}_{2}$ by the critical point method. The dried specimens were coated with gold in a JEOL Fine Coat sputtering apparatus and observed with a JEOL JSM-P15 scanning electron microscope.

\section{Results}

There were no vesicular follicles visible on the surface of the ovarian cortex from the infantile pig and the ovarian surface was smooth. It became uneven, however, because of the growing follicles at prepuberty and of both growing follicles and corpora lutea after puberty.

The surface epithelium of the ovary from the infantile pig consisted of polygonal cells that possessed numerous short microvilli (Figs. 1 3). A small number of long cilium-like processes were observed among the microvilli (Figs. 2, 3). Generally these microvilli were shorter and thicker than those found in the pig ovary at prepuberty or postpuberty.

In the prepuberal or postpuberal pig ovary, the surface epithelium was observed as a continuous cellular layer at a low magnification (Figs. 1,4). Each epithelial cell formed a hemispheric convexity directed outward. The epithelial cells were distinctly outlined by deep intercellular crevices (Figs. 2, 5, 7, 9). In general, the surface epithelium over the follicle was composed of polygonal cells covered with numerous microvilli, which varied in length and number (Figs.5 9), and a small number of cilium-like processes.

The size of surface epithelial cells covering a large follicle (Fig. 9) appeared to be somewhat larger than that of these over a small (Fig.5) or a medium-sized (Fig. 7) follicle. Also, the cells over the large follicle (Fig.9) possessed somewhat longer microvilli than did the cells over a small (Fig.5) or medium-sized (Fig.7) follicle. On the contrary, the surface epithelium showed no morphological differences when 


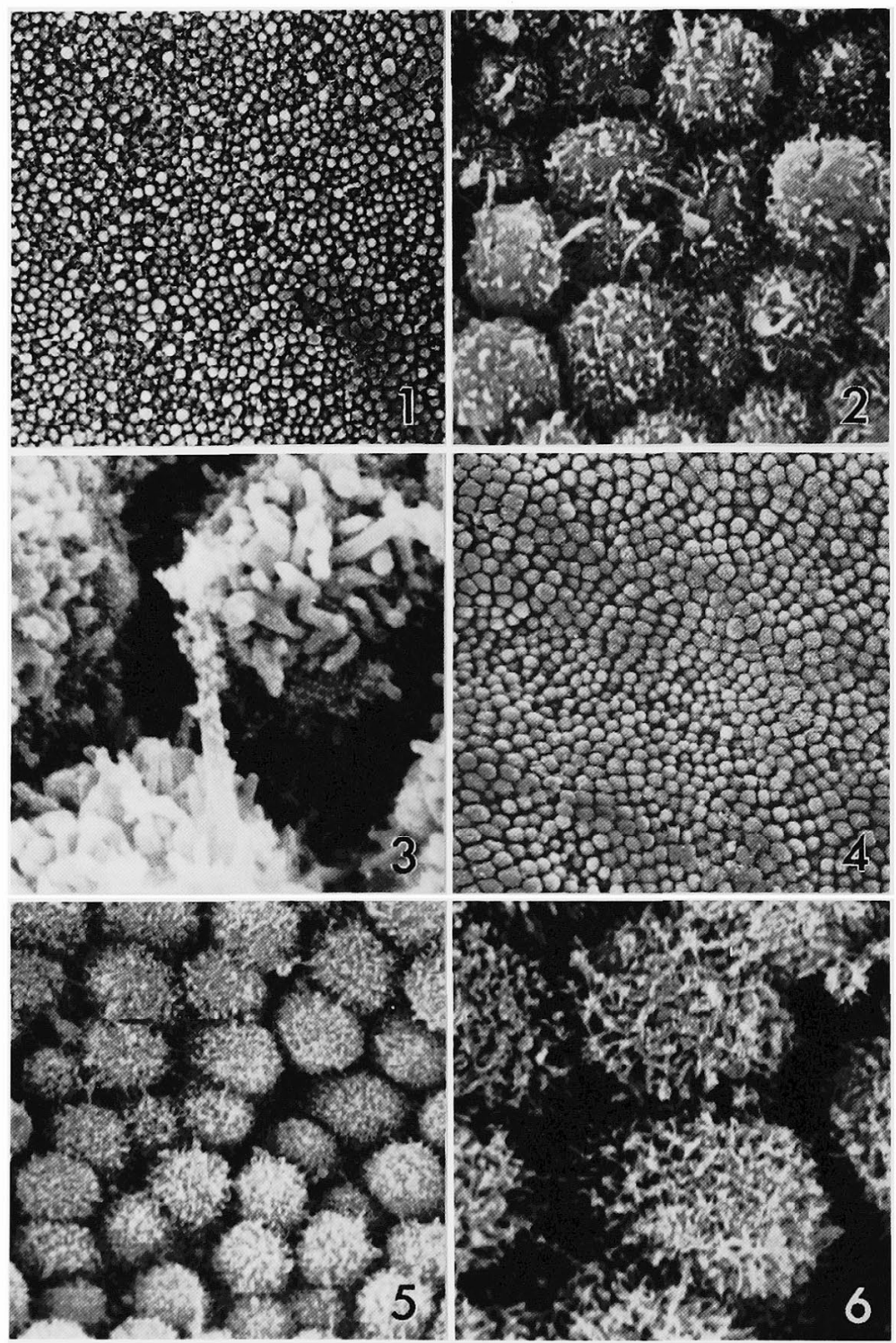

Explanation of Figures

Scanning electron micrographs of the surface epithelium of the pig ovary.

Fig. 1. The surface epithelium of an infantile pig ovary is observed as a continuous cellular layer. $\times 375$.

Fig. 2. The surface epithelium of an infantile pig ovary is made of polygonal cells covered with numerous short microvilli and some isolated cilium-like processes. $\times 3750$.

Fig. 3. A high magnification $(\times 15,000)$ of Fig. 2. Note a cilium-like process among the microvilli.

Fig. 4. This micrograph shows the presence of a continuous cellular layer covering a small follicle in a prepuberal pig ovary. $\times 75$.

Fig. 5. The surface epithelium over a small follicle in a prepuberal pig ovary is composed of polygonal cells with numerous microvilli. $\times 2,250$.

Fig. 6. A high magnification $(\times 6,000)$ of Fig. 5 . 


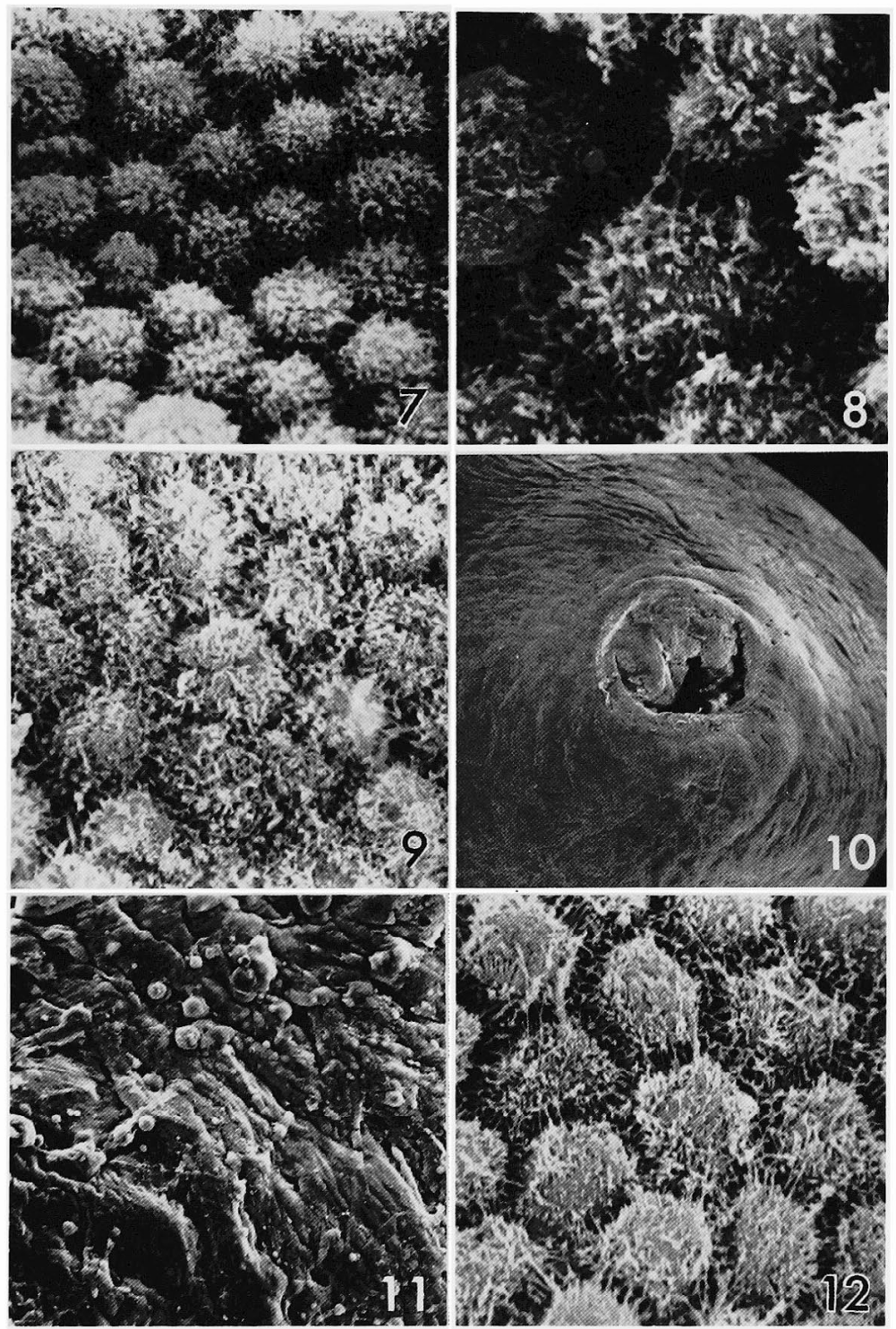

Fig. 7. The surface epithelium over a medium follicle from a prepuberal pig ovary. Epithelial cells are polygonal in shape and covered with numerous microvilli. $\times 2,250$.

Fig. 8. A high magnification $(\times 6,000)$ of Fig. 7 .

Fig. 9. The surface epithelium over a large follicle from a postpuberal pig ovary. These epithelial cells have numerous microvilli and are some what larger than those over a small (Fig. 5) or medium-sized (Fig. 7) follicle. $\times 2,250$.

Fig. 10. Ovulation point at early metestrus. The crater in the center of the ruptured follicle is slightly swollen. $\times 23$.

Fig. 11. This micrograph shows the apical surface of an ovulated follicle at early metestrus. The surface is covered with a gel-like material composed of follicular fluid. Epithelial cell structures are scarcely observed. $\times 375$.

Fig. 12. This micrograph shows the surface epithelial cells over a corpus luteum at diestrus. These cells, polygonal in shape, are covered with numerous microvilli. $\times 2,250$. 
covering follicles from one same size class, regardless of the stages of the estrous cycle they belonged to.

The ovulation point could be observed at early metestrus as a crater in the center of the ovulated follicle (Fig. 10). The apical surface was covered with a gel-like material composed of follicular fluid (Fig.11). The apical surface of the ovulated follicle (corpus luteum) differed in structure from the surface epithelium over the preovulated one. At early metestrus, epithelial cell structures in the apical region of the ovulated follicle were impossible to ascertain (Fig.11), although in some cases the cells showed fewer microvilli than did the cells over the pre-ovulated follicle. At late metestrus, the cell borders in the apical regions of these corpora lutea were indistinguishable even if cells were observed, but became distinct during diestrus. At diestrus, the epithelial cells covering the the corpora lutea possessed as many microvilli as did those covering pre-ovulated follicles (Fig. 12). In other regions, the structure of epithelial cells over the ovulated follicle appeared to be about the same as that of those covering the pre-ovulated follicle.

The surface epithelial cells essentially had the same appearance whether they covered a follicle or not, but interfollicular regions sometimes had cells with fewer microvilli than those over follicles.

\section{Discussion}

To our knowledge, there are no data to be directly compared with this study since scanning electron microscopic studies on the ovarian surface epithelium have not previously been reported for farm animals.

The present scanning electron microscopic study revealed that the surface epithelium of the pig ovary is observed as a continuous cellular layer at a low magnification and that the surface epithelium is composed of polygonal cells having numerous microvilli and a few isolated cilium-like processes. Even the ovarian surface epithelium of the infantile pig has essentially almost the same general appearance as epithelial cells of the pig at prepuberty or postpuberty.

The surface epithelium covering the ovarian follicle of the mouse ${ }^{1-3)}$, rat ${ }^{1,3-5)}$, hamster ${ }^{5,6)}$, guinea pig $^{11}$, rabbit ${ }^{1,3-5,7,8)}$, monkey ${ }^{4)}$ and human ${ }^{1,4,9)}$ consists of polygonal cells that are covered with microvilli. As for the pig, also, the morphological features of the ovarian surface epithelium were similar to those of laboratory animals ${ }^{1-8}$ ) and primates ${ }^{1,4,9)}$ mentioned above. When studied by scanning electron microscopy it appears, therefore, that there are no great variations among the mammalian species in the fine surface structure of the ovarian surface epithelium.

It is generally considered that the microvilli on the surface epithelium of organs within the body cavity increase the physiologically active surface area of the cell ${ }^{5}$. According to ANDREWS and PORTER ${ }^{15)}$, the microvilli harbor a layer of serous exudation and thereby create a slippery cushion which would serve to protect the surfaces of various organs from frictional damage.

Our experiments were not designed to clarify the role of ovarian epithelial cells 
in the pig. However, several theories have been proposed by other investigators to explain the role of the ovarian surface epithelium of laboratory animals ${ }^{2,10,11,16)}$ and humans $\mathrm{s}^{9}$. The ovarian surface epithelium may contribute to the production of degradative enzymes which help to disintegrate the follicle apex prior to rupture ${ }^{11,16)}$. It has been also reported that the morphological changes of the ovarian epithelial cells are probably associated with pronounced intracellular changes or progressive degeneration of the cells and with the luteinization of the follicle ${ }^{1,2,10)}$. Furthermore, it has been proposed that the microvilli and cilia on the surface epithelium of the human ovary possibly help the connection between the fimbria of the oviduct and the ovarian surface in order to catch the egg into the lumen of infundibulem ${ }^{9}$.

The present study provides new information regarding the morphology of the ovarian surface epithelium of the pig, while information regarding the function is left for future studies. Although several theories have been proposed as mentioned above, the functional significance of the ovarian surface epithelium is not yet well known. Hence, further studies are necessary for the clarification of the role of the ovarian surface epithelium in mammals, more particularly in farm animals.

\section{References}

1) Motta, P., D. D. Cherney and L. J. A. Diolo, J. Submicr. Cytol., 3: 85-100. 1971.

2) Nilsson, O. and S. R. Munshi, J.Submicr. Cytol., 5: 1-6. 1973.

3) Motta, P. and J. Van Blerkom, Am. J. Anat, 143: 241-264. 1975.

4) Tanaka, K., S. Sugawara and E. S. E. Hafez, in Scanning Electron Microscopic Atlas of Mammalian Reproduction. (Hafez, E.S. E. ed.) 112-117. Igaku Shoin Ltd. Tokyo. 1975.

5) Anderson, E., G. Lee, R. Le Tourneau, D. Albertini and S. Meller, J. Morph., 150: 135-166. 1976.

6) Pendergrass, P. B, and M. Reber, J.Reprod. Fert., 59: 21-24. 1980.

7) Cherney, D. D., P. Motta and L. J. A. Didio, J. Microscopie 17: 37-40. 1973.

8) Bjersing, L. and S. Cajander, Cell Tiss. Res., 149: 301-312. 1974.

9) Baccarini, I. M., Anat. Rec., 181: 305-306 (Abstr.). 1975.

10) Buskov, A. G. S., Z. Zellforsch., 100:285-299. 1969.

11) Cajander, S., Cell Tiss. Res., 173: 437-449. 1976.

12) Boda, J. M., in Reproduction in Domestic Animals. (Cole, H. H. and P. T. Cupps, eds.) 335357. Academic Press. New York. 1959.

13) DAY, B. N., in Reproduction in Farm Animals. 2 nd ed. (HAFEz, E. S. E., ed.) 279-288. Lea and Febiger. Philadelphia. 1968.

14) Dzruk, P. J., in Reproduction in Domestic Animals. (Cole, H. H. and P. T. Cupps, eds.) 455474. Academic Press. New York. 1977.

15) Andrews, P. M. and K. P. Porter, Anat. Rec., 177: 409-426. 1973.

16) Bjersing, L. and S. Cajander, Experientia, 31: 605-608. 1975. 


\title{
豚卵巣の表在上皮の走查電子顕微鏡による観察
}

\author{
宮本 元・古林亮介・石橋武彦 \\ 京都大学農学部，京都市 606
}

\begin{abstract}
豚卵巣の表在上皮の微細構造を明らかにするため，乙 の研究を行った.16 頭の未成熟または成熟豚から卵巣を 採取して，2.5\%ダルタルフルデヒドで固定し，1\%オス ミウム酸で後固定した.ついで臨界点乾燥の後, 金のイ オンスパッタコーティングを行い，走查電子顕微鏡で観 察した。13 日路の豚卵巣表面には卵胞法見られず, 表在 上皮細胞は多角形で軽く突出しており，多数の短い微䋨 毛で技おわれていた．これらの微䄉毛の間に少数の線毛 様突起が見られる細胞もあった. 6〜7月龄および成熟豚 の卵胞の衣在上皮細胞は，大部分の場合前述の13日龆の 卵巣表面之ほとんど同じ多角形であり，多数の微紷毛で おおわれていた，大卵胞 $(6 \sim 12 \mathrm{~mm})$ をおおっている表
\end{abstract}

在上皮細胞の大きさは，小卵胞 $(1 \sim 2 \mathrm{~mm})$ および中卵 胞 ( $3 \sim 5 \mathrm{~mm}$ ) のものより少し大きい傾向があった. ま た，大卵胞の表在上皮細胞の微絨毛は，小卵胞および中 卵胞のむのより少し長い傾向む見られた. 発情後期の初 期には，排卵点付近では表在上皮細胞はほとんど見られ なかった。発情後期には，排卵点付近にたと文表在上皮 細胞が存在しても細胞の輸郭は明暸でなく微䋐毛す少な いが，発情休止期には細胞の輪郭が明瞭になり，多数の 微䋐毛む観察された. 一般に, 走查電子顕微鏡で観察し た豚卵栄の表在上皮の微細構造は, 実験小動物拉よび䨝 長類のむのと類似していた.

日畜会報, $53(10)$ ：692-698, 1982 